\title{
Ossification Time of Distal Humeral Epiphyses by Gender in the Pre-pubertal Period
}

\section{Pre-pubertal Dönemde Humerus Distal Epifizlerinin Cinsiyete Göre Ossifikasyon Zamanı}

\author{
ه Mehmet Sabri Balık
}

Recep Tayyip Erdoğan University Faculty of Medicine, Department of Orthopaedic and Traumatology, Rize, Turkey

\section{Abstract}

Aim: It was aimed to determine the differences in time of physeal closure and the appearance of humeral distal epiphyses in the prepubertal period between genders.

Methods: Radiological data of the first 200 healthy children in the prepubertal period, who underwent diagnostic $\mathrm{X}$-ray imaging of the elbow due to the complaints of the elbow region between January 2012 and January 2017, were collected. The presence of lateral epicondyle, lateral condyle, trochlea, and medial epicondyle epiphysis cores on the elbow radiographs was classified and labeled by age and gender. The ages, in which the lines between lateral epicondyle and lateral condyle, lateral condyle and trochlea, medial epicondyle and humerus, humerus and lateral epicondyle, and lateral epicondyle and trochlea epiphyses were found to be closed, were documented by gender.

Results: Examining the mean ossification time by gender for lateral epicondyle, trochlea, medial epicondyle, and lateral condyle, this time was found to be nine months early, nine months early, 10 months early, and two months late for the girls, respectively. The mean physeal closure time in girls were found to be 13 months earlier for the lateral epicondyle-lateral condyle physis, seven months earlier for lateral condyle-trochlea physis, eight months later for lateral epicondyle-lateral condyle-trochlea-humerus physis, and nine months later for medial epicondyle-humerus physis.

Conclusion: In the literature, a delay was observed in ossification time of lateral condyle in girls and medial epicondyle in both genders. When compared with girls, the medial epicondyle and fusion times were found to be earlier in boys than in girls.

Keywords: Elbow, ossification center, epiphysis

\section{Öz}

Amaç: Puberte öncesi dönemde humerus distal epifizlerinin yaş ve cinsiyete göre görünme ve fiz hatlarının kapanma zamanındaki farklııklarının belirlenmesi amaçlanmıştır.

Yöntemler: Dirsek bölgesinde yakınma nedeniyle tanı amaçlı dirsek X-ray çekilen puberte öncesi sağlıklı toplam ilk 200 çocuğun radyolojik verileri toplandı. Olguların dirsek grafilerinde lateral epikondil, lateral kondil, troklea ve medial epikondilin epifiz çekirdeklerinin varlığı yaş ve cinsiyete göre sınıflandırılarak kayıt edildi. Lateral epikondil ile lateral kondil, lateral kondil ile troklea, medial epikondil ile humerus, humerus ile lateral epikondil lateral kondil troklea epifizleri arası hattın kapalı görüldüğü yaşlar cinsiyete göre dokümante edildi.

Bulgular: Ortalama ossifikasyon zamanı lateral epikondil, troklea, medial epikondil, lateral kondil için cinsiyete göre değerlendirildiğinde sırasıyla kızlarda dokuz ay erken, dokuz ay erken, 10 ay erken ve iki ay geç tesbit edildi. Fiz hatlarının ortalama kapanma zamanı cinsiyete göre değerlendirildiğinde kızlarda lateral epikondil-lateral kondil fiz hattı için 13 ay erken, lateral kondil-troklea fiz hattı için yedi ay erken, lateral epikondil-lateral kondil-troklea-humerus fiz hattı için sekiz ay geç, medial epikondil-humerus fiz hattı için dokuz ay geç tespit edildi.

Sonuç: Literatüre göre kızlarda lateral kondilin, her iki cinste ise medial epikondilin ossifikasyon zamanında gecikme vardı. Medial epikondil ve füzyon zamanı kızlarda erkeklerden daha erkendi.

Anahtar Sözcükler: Dirsek, ossifikasyon merkezi, epifiz
Address for Correspondence/Yazışma Adresi: Mehmet Sabri Balık Recep Tayyip Erdoğan University Faculty of Medicine, Department of Orthopaedic and Traumatology, Rize, Turkey

E-mail: sabribalik@yahoo.com ORCID ID: orcid.org/0000-0001-9729-3927

Received/Geliş Tarihi: 11 September 2018 Accepted/Kabul Tarihi: 07 February 2019
${ }^{\circ}$ Copyright 2019 by The Medical Bulletin of University of Health Sciences Haseki Training and Research Hospital

The Medical Bulletin of Haseki published by Galenos Yayınevi.

Telif Hakkı 2019 Sağlık Bilimleri Üniversitesi Haseki Eğitim ve Araștırma Hastanesi Haseki Tıp Bülteni, Galenos Yayınevi tarafından yayıllanmıştır. 


\section{Introduction}

The skeletal system has significant contribution to the physical growth of the human body. This process is based on the proliferation of the cartilage tissue named "chondroplasia" in long bones. The bone development begins in diaphysis during the intrauterine period as the primary ossification period. It continues as the secondary ossification center after birth. In this period, the epiphysis cores are formed. The shape and size of epiphysis cores and their relationship with diaphysis show the growth potential of bone. During the growth period, there is the cartilage between metaphysis and epiphysis (1).

The timing of ossification of bones in the period of growth after birth differs. Puberty plays a role in the beginning of the ossification of the epiphysis zones. The factors affecting the beginning of puberty are genetic ones (2), intrauterine factors (3), nourishment (4), geographic and climatic conditions (3), chronic diseases (5), physical stress $(3,6)$, psychological state $(7)$, materials damaging the endocrine system (2), and migration (3). In addition to these factors, the onset of puberty also varies between girls and boys. Boys usually start puberty two years later than girls. For this reason, gender is one of the main determinants of ossification time $(8,9)$.

Traumatic injuries to the locomotor system including the elbow region are frequently observed in the pre-pubertal period. The ossification centers distal to the humerus in children during the pre-pubertal period have a complex anatomic structure. It might complicate the differential diagnosis of injuries affecting the elbow region. They are important since these injuries are frequently observed and they deteriorate the functions of the elbow joint (10-12).

Imaging methods are used in examining the elbow after injury, especially those affecting the bone tissue. Elbow radiography is the first option in imaging. The complex variable anatomic structure, age, and genderbased differences in the pre-pubertal period of children should be considered in analyzing direct radiographies of the elbow joint (13-16).

In the present study, it was aimed to determine the timing of physeal closure and appearance of distal humeral epiphyses in children in the pre-pubertal period living in our region.

\section{Methods}

The radiological data of the first 200 healthy children in the pre-pubertal period, who attended Recep Tayyip Erdoğan University Training and Research Hospital with the complaints of the elbow region between January 2012 and January 2017 and then underwent diagnostic elbow X-ray imaging, were analyzed by an orthopedist. Patients having bilateral X-ray image showing the elbow region were involved in the present study. Those having a history of fracture in the elbow region, metabolic and chronic disease, detected to have osseous pathology on radiographs, and having image with insufficient quality for evaluation were excluded.

For all the cases, the closure of the line between epiphyses and the ossification of distal humeral epiphyses were analyzed using the elbow images. In this analysis, the presence of lateral epicondyle, lateral condyle, trochlea, and medial epicondyle epiphysis cores was classified and labeled by age and gender. The ages, in which the lines between lateral epicondyle and lateral condyle, lateral condyle and trochlea, medial epicondyle and humerus, humerus and lateral epicondyle, and lateral epicondyle and trochlea epiphyses were found to be closed, were documented by gender. They were grouped based on the timing of physeal closure.

This retrospective study was carried out in accordance with the principles outlined in the Declaration of Helsinki. For searching archived material and reserch permission was obtained from the hospital administration, and it was affirmed by the Recep Tayyip Erdoğan University local ethics commitee (approvel number: 22).

\section{Statistical Analysis}

The normality of data distribution was analyzed using the Kolmogorov-Smirnov test. The central tendency of parametric ones among the numeric data was expressed as mean value and standard deviation. The non-parametric ones were expressed as median and interquartile range. In the figures, the ossification and fusion time ranges of the cases are presented. SPSS (Statistical Package for the Social Sciences) software 17.0 (SPSS Inc, Chicago, IL, USA) was used in all of the analyses.

\section{Results}

$30 \%$ of the subjects were girl and $70 \%$ were boy. The mean age of lateral epicondyle ossification was 142 months for the boys and 133 months for the girls. That of trochlea ossification was found to be 143 months for boys and 134 months for girls. The mean age of medial epicondyle ossification was determined to be 120 months for boys and 110 months for girls. Finally, the mean age of lateral condyle ossification was found to be 78 months for boys and 80 months for girls. The distribution of mean ages, in which the distal humeral epiphysis was ossified (Table 1) or not, by gender is presented in Figure 1 for all subjects. 

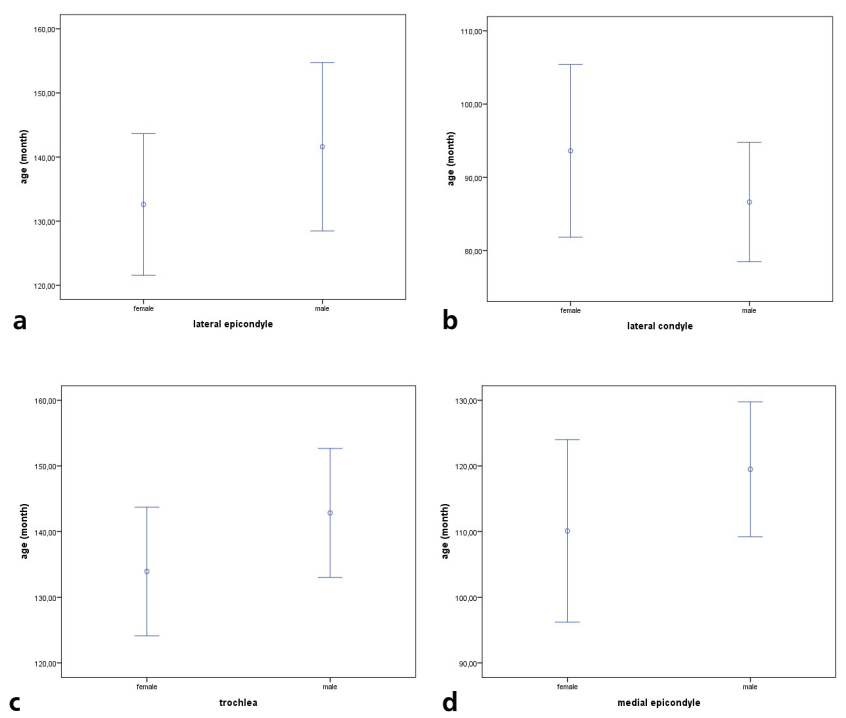

Figure 1. The distribution of the mean ages of ossification and non-ossification of distal humerus a. lateral epicondyle, b. lateral condyle, c. trochlea, and d. medial epicondyle epiphyses

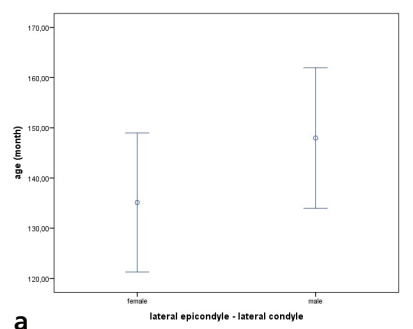

a

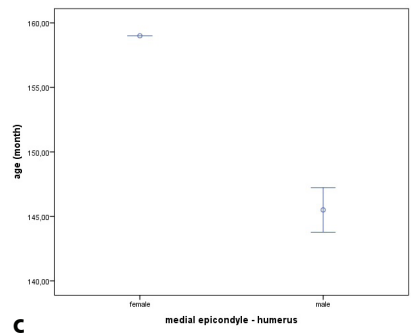

b
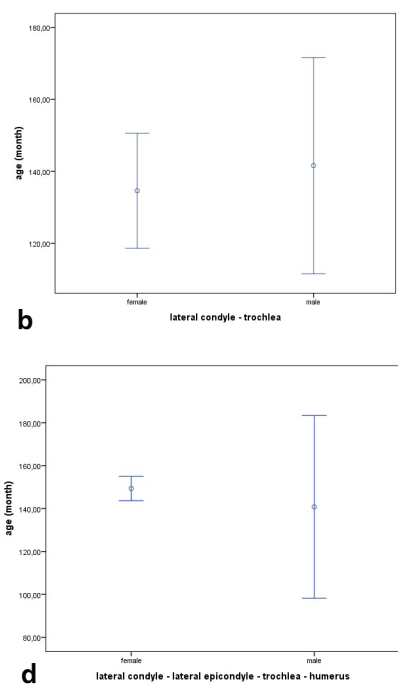

Figure 2. The distribution of the ages of fused and nonfused physes (among the distal humeral epiphyses) a. Lateral epicondyle + lateral condyle, b. Lateral condyle + trochlea, c. Medial epicondyle + humerus, d. Lateral epicondyle + lateral condyle + trochlea + humerus by the gender

\begin{tabular}{|l|l|l|l|l|l|}
\hline \multicolumn{2}{|l|}{ Table 1. The distribution of mean age of ossification of distal humeral epiphyses by the gender } \\
\hline No & Localization & & $\begin{array}{l}\text { Male } \\
\text { (month) }\end{array}$ & $\begin{array}{l}\text { Female } \\
\text { (month) }\end{array}$ & $\begin{array}{l}\text { Difference } \\
\text { (month) }\end{array}$ \\
\hline 1 & Lateral epicondyle & Appear mean (SER) & $142(7)$ & $133(5)$ & 9 \\
\hline 2 & Lateral condyle & Appear mean (SER) & $78(166)$ & $80(102)$ & 2 \\
\hline 3 & Trochlea & Appear mean (SER) & $143(5)$ & $134(5)$ & 9 \\
\hline 4 & Medial epicondyle & Appear mean (SER) & $120(5)$ & $110(7)$ & 10 \\
\hline SER: Supination external rotation & & & & \\
\hline
\end{tabular}

\begin{tabular}{|l|l|l|l|l|l|}
\hline \multicolumn{2}{|l|}{ Table 2. The distribution of mean ages of closure of lines between the distal humeral epiphyses by the gender } \\
\hline No & Localization & & $\begin{array}{l}\text { Male } \\
\text { (month) }\end{array}$ & $\begin{array}{l}\text { Female } \\
\text { (month) }\end{array}$ & $\begin{array}{l}\text { Difference } \\
\text { (month) }\end{array}$ \\
\hline 1 & Lateral epicondyle + lateral condyle & $\begin{array}{l}\text { Fused } \\
\text { mean (SER) }\end{array}$ & $148(7)$ & $135(7)$ & 13 \\
\hline 2 & Lateral condyle + trochlea & $\begin{array}{l}\text { Fused } \\
\text { mean (SER) }\end{array}$ & $142(14)$ & $135(7)$ & 7 \\
\hline 3 & Medial epicondyle + humerus & $\begin{array}{l}\text { Fused } \\
\text { mean (SER) }\end{array}$ & $146(1)$ & $155(9)$ & 9 \\
\hline 4 & Lateral condyle + lateral epicondyle Trochlea + humerus & $\begin{array}{l}\text { Fused } \\
\text { mean (SER) }\end{array}$ & $141(18)$ & $149(2)$ & 8 \\
\hline SER: Supination external rotation & & & \\
\hline
\end{tabular}

The mean age of the closure of lateral epicondylelateral condyle physis line was 148 months for boys and 135 months for girls. That of lateral condyle-trochlea physis line was 142 months for boys and 135 months for girls. The mean age of closure of lateral epicondyle-lateral condyle-trochlea-humerus physis line was found to be 141 months for boys and 149 months for girls.
Finally, the mean age of the closure of medial epicondyle-humerus physis line was 146 months for boys and 155 months for girls. The distribution of the mean age of physeal closure in the distal humerus by gender is shown in Table 2. The distribution of the age of non-fused physis cases by gender is presented in Figure 2 . 


\section{Discussion}

Injuries to the elbow region are frequently seen during the childhood period. They constitute $15 \%$ of all the pediatric fracture cases. Approximately $85 \%$ of these fractures involve the distal humerus (11). Early diagnosis and treatment is important for these injuries because fractures in children heal rapidly. If bone recovery in an appropriate position cannot be achieved during the early phase of elbow trauma, no successful outcome can be obtained (17). For this reason, in order to optimize the treatment outcomes in children with elbow injuries, accurate and very early diagnosis is very important for the treatment planning (10). When compared to others, fractures in the pre-pubertal period are more frequently misdiagnosed in the first examination (18) because the distal humerus has a complex anatomic structure consisting of ossification centers. The complex joint construction and the age-dependent appearance of epiphyseal ossification centers sometimes make a accurate radiological diagnosis difficult (10). After elbow trauma, a fracture including the ossification centers may occur. The visibility of ossification centers on radiographs during the growth period of children shows variability. Since non-ossified cartilage is radiolucent, it may cause a difficulty during diagnosis. For this reason, delays may occur during the diagnostic process. The undiagnosed fragment may be displaced. These processes may cause malunion, nonunion, and limited joint mobility, as well as neural damages. All these factors may bring the risk of loss of function in the extremity. While making radiological examination after injuries to the elbow region, having the full knowledge of anatomical structures including the ossification centers is very important for accurate diagnosis and early treatment $(10,19,12)$. For these reasons, both imaging the ossification centers in the elbow region and the fusion timing drew the attention of researchers in the literature (20-22).

Imaging the ossification centers and the timing of fusion are also important in determining bone age during examination after trauma. In the Greulich and Pyle atlas, especially the elbow radiographs are utilized because of the difficulty in determining bone age in the prepubertal period (8). Bone age determination is required in evaluations before extremity epiphysiodesis or deformity reconstruction surgeries. The distal humeral ossification centers can be used in determining bone age because bone age is correlated with chronologic age in majority of healthy children $(8,9)$.

The beginning of puberty differs between girls and boys. According to bone age, the average age for girls to begin puberty is 11 and for boys the average age is 13 .
Puberty ends by 13 for girls and 15 for boys. Since there is a two year difference between physical development of boys and girls, boys mature two years later (8). In both genders, there is a possibility of morphological change in the distal humerus. This morphologic change occurs in a six month period $(8,9,23)$.

Many studies have been carried out for determining the time of appearance of ossification centers around the elbow (22,24-25). In their study, Cheng et al. (22) reported that there was no difference between genders in terms of the time of appearance of ossification centers around the elbow. On the other hand, Bajaj et al. (24) reported a delay in appearance of ossification centers around the elbow in Indian males. Similarly, Reed (25) also reported a delay in ossification among males. Garn et al. (26), however, reported an ossification delay in medial epicondyle for males and in lateral epicondyle for females.

In the present study, a delay was observed in the lateral condyle ossification time in girls on elbow radiographs. Among boys, the delay was observed in the ossification time in medial epicondyle, trochlea, and lateral epicondyle. However, on the contrary with the literature, the delay in ossification time was not longer than a year for both genders. Our data also corroborated the paradox about ossification time in the literature.

Among the distal humeral ossification centers, ossification of lateral condyle occurs before the age one (20), that of medial epicondyle between the ages five and six $(20,25-27)$, that of medial condyle between the ages nine and 10 (20), and that of lateral epicondyle between the ages 10 and $12(20,22,24,26,27)$. In the present study, the ossification times of lateral epicondyle, trochlea, and lateral condyle observed in the elbow radiographs were in harmony with the literature. However, when compared with the literature, there was a delay in the ossification time of the medial epicondyle. On the contrary with the present study, Klatt and Aoki (21) determined that the medial epicondyle showed much less variation than skeletal maturation. However, supporting the results reported in the present study, Bajaj et al. (24) and Procell Villalobos et al. (20), reported a delay in the ossification of medial epicondyle in their study. These results suggest that the differences in ossification time may depend on various factors.

\section{Study Limitations}

The main limitation of the present study is the limited number of cases. Despite that, because knowing the ossification centers and variations of elbow region is an advantage for the clinician from the aspect of early diagnosis, the present study is important since there are differences in the appearance of the elbow region 
ossification centers and in fusion times when compared with the literature (12).

\section{Conclusion}

In conclusion, when compared with the literature, delays were observed in ossification of the lateral condyle in girls and medial epicondyle in both genders in the present study. The medial epicondyle and fusion times were found to be earlier among girls when compared to boys. Moreover, the ossification and fusion times of these centers had a very wide range for both genders. For this reason, a national database should be established in order to ensure the standardization in evaluating the ossification and fusion times of epiphysis cores at the distal humerus. For this purpose, further large-scale studies are warranted.

Financial Disclosure: The authors declared that this study received no financial support.

\section{References}

1. Neyzi O, Ertuğrul T. Pediatric. 2. edition. İstanbul: Nobel Medical Bookstores, 1993, 61-100.

2. Bourguignon JP. Control of the onset of puberty. In: Pescovitz $\mathrm{OH}$, Eugster EA (eds). Pediatric Endocrinology: mechanisms, manifestations and management. Philadelphia: Lippincott Williams \& Willkins; 2004, 285-98.

3. Parent AS, Teilmann G, Juul A, Skakkebaek NE, Toppari J, Bourguignon JP. The timing of normal puberty and the age limits of sexual precocity: variations around the world, secular trends, and changes after migration. Endocr Rev 2003;24:668-93.

4. Styne DM. Puberty, obesity and ethnicity. Trends Endocrinol Metab 2004;15:472-8.

5. Büyükgebiz A, Böber E. Delayed puberty and other pubertal problems. Günöz H, Öcal G, Yordam N, Kurtoğlu S. Pediatric Endocrinology. Kayseri: Pediatric Endocrinology and Oxygen Society Publications; 2003:189-213.

6. Georgopoulos N, Markou K, Theodoropoulou A, et all. Growth and pubertal development in elite female rhythmic gymnasts. J Clin Endocrinol Metab 1999;84:4525-30.

7. Tahirovic HF. Menarchal age and the stress of war: an example from Bosnia. Eur J Pediatr 1998;157:978-80.

8. Canavese F, Charles YP, Dimeglio A. Skeletal age assessment from elbow radiographs. Review of the literatüre Chir Organi Mov 2008;92:1-6.

9. Charles YP, Canavese F, Dimeglio A. Skeletal age determination from the elbow during pubertal growth. Orthopade 2005;34:1052-3.

10. Weise K, Schwab E, Scheufele TM. Elbow injuries in childhood. Unfallchirurg 1997;100:255-69.

11. Shrader MW.Pediatric supracondylar fractures and pediatric physeal elbow fractures. Orthop Clin North Am 2008;39:16371.
12. Jacoby SM, Herman MJ, Morrison WB, Osterman AL.Pediatric elbow trauma: an orthopaedic perspective on the importance of radiographic interpretation. Semin Musculoskelet Radiol 2007; 11:48-56.

13. Carey J, Spence L, Blickman H, Eustace S. MRI of pediatric growth plate injury: correlation with plain film radiographs and clinical outcome. Skeletal radiology 1998;27:250-5.

14. Ruffing T, Danko T, Henzler T, Weiss C, Hofmann A, Muhm M. Number of positive radiographic findings in pediatric trauma patients. Emerg Radiol 2017;24:281-6.

15. Iyer RS, Thapa MM, Khanna PC, Chew FS. Pediatric bone imaging: imaging elbow trauma in children-a review of acute and chronic injuries. AJR Am J Roentgenol 2012;198:105368.

16. Jacob A, Khan S. Radiology of acute elbow injuries. Br J Hosp Med 2010;71:6-9.

17. Louahem DM, Bourelle S, Buscayret F, et al. Displaced medial epicondyle fractures of the humerus: surgical treatment and results. A report of 139 cases. Arch Orthop Trauma Surg 2010;130:649-55.

18. Skaggs D, Pershad J. Pediatric elbow trauma. Pediatr Emerg Care 1997;13:425-34.

19. Beaty JH, Kasser JR (eds). Rockwood and Wilkins' fractures in children. 7nd edition. Philadelphia: Lippincott Williams \& Wilkins; 2010, 488-532.

20. Procell Villalobos CR, Cassis Zacarías N, Juárez Rojas CS, Cárdenas Turrent MB. Order of appearance of ossification centers in the elbow of Mexican children between 6 months and 12 years old. Acta Ortop Mex 2008;22:347-9.

21. Klatt JB, Aoki SK. The location of the medial humeral epicondyle in children: position based on common radiographic landmarks. J Pediatr Orthop 2012;32:477-82.

22. Cheng JC, Wing-Man K, Shen WY, et al. A new look at the sequential development of elbow-ossification centers in children. J Pediatr Orthop 1998;18:161-7.

23. Sahni D, Jit I. Time of fusion of epiphyses at the elbow and wrist joints in girls of northwest India. Fornsic Sci Int 1995;74:47-55.

24. Bajaj ID, Bhardwaj OP, Bhardwaj S. Appearance and fusion of important ossification centers: a study in Delphi population. Indian J Med Res 1967;55:1064-7.

25. Reed MH. Pediatric skeletal radiology: appendicular skeleton. Williams \& Wilkins, Baltimore, 1992, 352-7.

26. Garn SM, Rohmann CG, Silverman FN. Radiographic standards for postnatal ossification and tooth calcification. Med Radiogr Photogr 1967;43:45-66.

27. Girdany BR, Golden R. Centers of ossification of the skeleton. AJR 1952;68:922-4. 